\title{
Przedsiębiorczość indywidualna, rodzinna, lokalna. Inicjatywa gospodarcza na początku XXI wieku w gminie Nowy Targ
}

\begin{abstract}
Marta Satyga*
W pracy przeprowadzono antropologiczna analize inicjatyw gospodarczych $w$ gminie Nowy Targ na Podhalu. Przedstawione zostato podtoże kulturowe, w którym szczególna funkcję petnia rodzina i rodzinne gospodarstwo. Omówiono opozycje takie jak: dom-świat zewnętrzny/ państwo, praca-robota, praca-dorabianie, a także wieloletnia tradycje emigracji zarobkowej. Zostat także poruszony aspekt mitu górala jako źródta wspótczesnej przedsiębiorczości lokalnej. Zaproponowano przyjęcie szerokiej perspektywy analizy przedsiębiorstwa, zawierającej opis uwarunkowań rodzinnych jednostki. Istotnym czynnikiem wspótczesnej, góralskiej przedsiębiorczości staje się użycie Internetu. Popularyzacja tego medium nie tylko otworzyta przed mieszkańcami Podhala nowe możliwości ekonomiczne, ale także pokazała szereg różnic spotecznych. Najważniejsze z nich, warunkujące kształt osobistej przedsiębiorczości, to pteć kulturowa, wiek $i$ wyksztatcenie.
\end{abstract}

Słowa kluczowe: Podhale, wieś, Internet, przedsiębiorczość, rodzina.

Nadesłany: 15.09.2015 | Zaakceptowany do druku: 31.03.2016

\section{Personal, family, local entrepreneurship.}

Economic initiative at the beginning of XXIth century at Nowy Targ Commune

This paper shows an anthropological analysis of economic initiatives at Nowy Targ Commune in Podhale. Firstly, cultural background is described, in which family and family farm have a crucial meaning. Furthermore, such oppositions as: home-external world/state, intellectual work-manual labor, to work-to moonlight, and also long-term tradition of labour migration are discussed. This article proposes a wide perspective of business' analysis, containing family causation of an individual. The Internet becomes an essential aspect of present, highlanders' entrepreneurship. Popularization of this new medium not only brought new economic possibilities for Podhale dwellers, but also highlighted many social differences. The most important ones, shaping personal entrepreneurship, are gender, age and received education.

Keywords: Podhale, village, Internet, entrepreneurship, family.

Submitted: 15.09.2015 | Accepted: 31.03.2016

JEL: R220

\footnotetext{
* Marta Sałyga - Instytut Etnologii i Antropologii Kulturowej Uniwersytetu Warszawskiego.

Adres do korespondencji: ul. Żurawia 4, 00-503 Warszawa; e-mail: marsalyga@wp.pl.
} 


\section{Wstęp}

Celem pracy było prześledzenie czynników nadających kształt ludzkim pomysłom na zarabianie. Najczęściej takie uwarunkowania wpisywały się w szerszą perspektywę prawidłowości społecznych. Kategoriami o wielkim wplywie na osobiste zainteresowania ekonomiczne okazały sie w szczególności wykształcenie, płeć kulturowa i wiek. Jednocześnie każdy z tych elementów pozostawał $\mathrm{w}$ relacji $\mathrm{z}$ lokalnym kontekstem góralskiej gminy i dziedzictwem góralskiej tradycji. Badania zostały przeprowadzone we wsiach gminy Nowy Targ, w powiecie nowotarskim w województwie małopolskim, gdzie mieszkają około 22 tysiace osób. Osoby uczestniczace w badaniu były w różnym wieku (od 85 do 25 lat), miały różną sytuację ekonomiczną bądź rodzinną, jednak wszyscy mieszkali i wywodzili się z okolic Nowego Targu. Ten teren badawczy był dla mnie szczególnie interesujący ze względu na silne poczucie grupowej tożsamości mieszkańców i mieszkanek Podhala. Jednocześnie, górale i góralki są od lat opisywani jako ludzie kształtujący swoja tożsamość wokół pracy i samodzielności finansowej. Warto także zaznaczyć, że to właśnie fizyczna praca jest tutaj słowem kluczowym: „przedsiębiorczość” to określenie, które jest używane opisowo, lecz pojęcie jako takie nie przeniknęło do języka potocznego. Mimo tego moi rozmówcy i rozmówczynie spełniaja postulat Josepha Schumpetera: nie dostarczają zupełnie nowych rozwiązań, ale rozwijają dostępne wzorce (Schumpeter, 1960).

W artykule chce zaproponować antropologiczną perspektywę $\mathrm{W}$ analizowaniu sytuacji ekonomicznej polskiej wsi. Będę odwoływać się do literatury etnograficznej i socjologicznej, co, mam nadzieję, pozwoli mi na ukazanie złożoności i wieloletniości przedstawionych zagadnień. W mojej analizie prace rozumiem jako „wydatkowanie wysiłku fizycznego, psychicznego i emocjonalnego w celu wytwarzania dóbr i usług do konsumpcji własnej lub przez innych" (Marshall 2004, s. 252). Tak szeroka definicja pozwala na równoprawne potraktowanie zarówno pracy na etacie, w ,szarej strefie", jak i zajęć domowych. Moje podstawowe pytanie badawcze brzmiało: dlaczego moi rozmówcy i rozmówczynie zdecydowali się na taką formę inicjatywy gospodarczej? Jaką rolę odegrały ich oso- biste uwarunkowania? Próbując odpowiedzieć na to pytanie, w latach 2011-2013 kilkukrotnie odwiedziłam gminę Nowy Targ. W tym czasie przeprowadziłam swoje badania, używajac klasycznych narzedzi z metodologii etnograficznej. Szczególnie istotna była dla mnie obserwacja życia nowotarskiej ludności oraz pogłębione wywiady z przedstawicielami i przedstawicielkami tej społeczności. Najwięcej czasu poświęciłam na rozmowy z osobami z Nowego Targu i okolicznych wsi: Pyzówki, Maruszyny czy Ludźmierza. Podczas prowadzenia wywiadu przestrzegałam luźno zarysowanego scenariusza, jednak nie posługiwałam się kwestionariuszem. Istotne było dla mnie stworzenie możliwości swobodnej wypowiedzi, podczas której rozmówcy i rozmówczynie w komfortowy dla siebie sposób opisywali własne życie. Po dwóch latach mój materiał obejmował kilkadziesiąt godzin nagrań, notatki terenowe i dokumentację fotograficzną. W trakcie badań na bieżąco poddawałam materiał wstępnej analizie, dzięki czemu mogłam dopasować swoje podejście do uzyskanej wiedzy. Projekt był skoncentrowany na długotrwałym kontakcie $\mathrm{z}$ badanym terenem, gdzie stosowałam metody jakościowe. Uzyskany w ten sposób materiał wymaga głębokiej analizy i znajomości kontekstu kulturowego, rzadko pozwala się przełożyć na konkretne liczby.

Tradycję rozumiem, za Ericiem Hobsbawnem (2008), jako potężny aparat pojęciowy, wynikający z ludzkich przekonań i wpływający na nie. Tradycja jest płynną strukturą, stale przetwarzaną i otrzymującą nowe znaczenia. Moi rozmówcy często powoływali się na pewna niewerbalizowaną esencję obecną w każdym góralu, określającą jego charakter, spryt, gospodarność i skłonność do ciężkiej, fizycznej pracy. Moim zdaniem jednym z kluczowych aspektów regionalnego uwarunkowania przedsiębiorczości jest, obecny w różnych formach, mit górala. W XIX wieku, wraz z narodzinami podhalańskiej turystyki, miejscy intelektualiści rozpoczęli kreowanie wizerunku górali jako osób o licznych zaletach, zaradnych, odważnych, przenikliwych, lojalnych... Dodatkowym bodźcem do podkreślania i uatrakcyjniania swojej odmienności były ekonomiczne zyski z przyjazdu wczasowiczów, zatem „góralski folklor" od swoich początków miał w sobie wymiar komercyjnego produktu. Mit górali przetrwał dekady dzięki instytucjonalnemu 
wsparciu, takim jak przyzakładowe zespoły folklorystyczne, działalność Cepelii, ale także dzięki sentymentowi i promocji przez księdza Józefa Tischnera i Jana Pawła II. Dzisiaj to sami Podhalanie kultywują swój stereotyp (Małanicz-Przybylska, 2013). Według Frances Pine, wieloletniej badaczki polskich górali, mieszkańcy i mieszkanki Podhala uważaja przestrzeń rodziny i domu (a przez 1989 rokiem - rodzinnego gospodarstwa rolnego) za rdzeń swojej tożsamości i najważniejszy element życia. Poprzez przynależność do domu konstruowała się osobowość człowieka, a także jego relacje społeczne i status we wspólnocie. To w budowanie domu inwestowano zdobyte środki; jego dobrobyt był świadectwem pracy gospodarzy. Dom miał być opozycją wobec świata zewnętrznego, świata obcych ludzi z miasta i nieprzyjaznego aparatu państwowego (2002). Emilia Sułek wyróżnia pracę jako jedną z idei łączących Podhalan z państwem. Otóż po władzach państwowych oczekiwano stworzenia odpowiedniego rynku pracy. Praca jest dla górali zjawiskiem absolutnie niezbędnym, koniecznym do zachowania dobrej kondycji osobistej oraz społecznej (2005). Kraj jest w tym kontekście widziany jako gospodarstwo, którym powinien zarządzać pojedynczy, sprawiedliwy i zapobiegliwy gospodarz. Rząd polski, jako dobry gospodarz, powinien umiejętnie rozdzielić obowiązki, tak aby każdy obywatel był w stanie utrzymać się ze swojej pracy (Malewska-Szałygin 2008).

Polscy górale podhalańscy to potomkowie pasterzy wołoskich, ale także osadników ruskich, niemieckich i słowackich. Pierwsza odnotowana, masowa migracja zarobkowa górali odbyła się po epidemii cholery w 1831 roku (Tylkowa, 2000). Od połowy XIX wieku do lat 50. XX wieku był to region zmagający się $\mathrm{z}$ biedą, od końca XIX wieku obecna jest stała migracja zarobkowa: przez dziesięciolecia do USA, dziś także do bogatych państw Unii Europejskiej. Według Pine poczatek socjalizmu to moment, w którym górale włączyli się w ekonomię państwową. Wtedy też nastąpiła zmiana trybu życia: rolnictwo zaczęto łaczyć z praca na etacie. Praca państwowa stała się jednocześnie gwarancją opieki socjalnej i symbolem wdarcia się państwa w autonomiczny, góralski dom. Praca na zewnątrz domu, poza wspólnotą, wynagradzana finansowo, była przeciwień- stwem tradycyjnego, rodzinnego podziału obowiązków i szerokiego systemu sąsiedzkiej pomocy. Moralna praca w rodzinnym gospodarstwie i źle oceniana praca państwowa były sobie przeciwstawiane, jak kapitalizm wobec komunizmu. Jedyną znana góralom forma kapitalizmu był system ekonomiczny Stanów Zjednoczonych. USA stały się dla mieszkańców Podhala symbolem wolności, choć emigranci pracowali w bardzo ciężkich warunkach. Ich praca przynosiła jednak wielką korzyść całej, pozostałej w Polsce, rodzinie. Jedną ze zmian po roku 1989 była zmiana postrzegania pracy na etacie - stała się mniej dostępna i cenna, gdyż zapewniała stały dochód. Nastąpiło też rozluźnienie sąsiedzkiej, wspólnotowej sieci pomocy (2002).

\section{Jak pracują górale i góralki?}

Długotrwałe, stacjonarne badania etnograficzne pozwalają na głębsze i bardziej kompleksowe poznanie badanej społeczności. Jedną z zalet takiej metody jest możliwość zapoznania się z środowiskiem społecznym rozmówców i rozmówczyń (Hammersley i Atkinson, 2000). Uważam, że analiza przedsiębiorców i przedsiębiorczyń w ramach ich sieci powiązań społecznych jest szczególnie cenna w kontekście polskich górali. Takie przedstawienie pozwala zauważyć silną zależność między podjętym zajęciem a statusem społecznym i kompetencjami rodzinnymi.

Dlatego w swoim opisie postaram się zawrzeć nie tylko charakterystykę firmy konkretnego rozmówcy, ale także dynamikę między zajmowanym stanowiskiem a rolą w rodzinie. Mój rozmówca, pięćdziesięcioletni mężczyzna, podobnie jak wielu jego podhalańskich rówieśników spędził około dwadzieścia lat w Stanach Zjednoczonych, pracując w firmie transportowej jako kierowca. Po powrocie do kraju stworzył firmę opartą na wzorcach przyswojonych za granicą. Większość zleceń dociera do firmy dzięki giełdzie internetowej, jednak właściciel nie potrafi z niej korzystać. Za działalność firmy w Internecie (czyli prawie całą jej działalność) odpowiadała jego córka (kobieta pracowała w firmie ojca, nie podejmując innych inicjatyw ekonomicznych). Jego syn, dzięki finansowemu wsparciu rodziny, założył natomiast stadninę - posiada kilkadziesiąt koni, organizuje konkursy jeździeckie, przejazdy 
stylizowanymi bryczkami i zajęcia z hipoterapii. Hodowla zwierząt jest wśród górali powszechna, jednak w tym regionie rolnicy mają zwykle krowy i korzystają z dotacji Unii Europejskiej. Stadnina koni wierzchowych jest jednocześnie związana z tradycyjnie pojmowaną góralszczyzną (Tylkowa, 2000), a zarazem jest przedsięwzięciem lokalnie niecodziennym, dostepnym tylko dla osoby bardzo zamożnej. Mężczyzna cenił promocję w social media, jednak sam miał lekceważący stosunek do użytkowania Internetu, podobnie jak ojciec przekazał te kompetencję dalej, jak to ujął: „dziewczynom ze stajni", swoim podwładnym.

Druga część opisywanej rodziny mieszka w pobliskiej wsi. Tam relacje rodzinne także są dość hierarchiczne, jednak głową rodziny jest kobieta, żona, matka, właścicielka pensjonatu i firmy cateringowej. Jej przedsiębiorstwo to obecnie duża firma, wpływająca na sytuację całej miejscowości - nie tylko pobudza ruch turystyczny, ale także oferuje czasowe zatrudnienie osobom (głównie kobietom) w trudnej sytuacji finansowej. Według moich obserwacji owa gospodyni (która sama siebie nazywała kucharką, nie businesswoman) cieszyła się w okolicy nieskazitelną opinią, dzięki ciężkiej fizycznej pracy jako kucharka i sprzątaczka w pensjonacie, dzięki wykreowaniu od zera ogromnego przedsiębiorstwa, oraz właśnie dzięki pozytywnemu wpływowi na lokalną społeczność. Córka tej gospodyni łączy rolę młodej matki z etatem urzędniczki oraz wytwarzaniem i sprzedażą biżuterii. Syn jest zaś informatykiem i należy do rosnącej grupy nowotarskich absolwentów uczelni wyższych, od kilku lat prowadzi własną firmę. Nie uzyskał kredytu na kapitał początkowy, więc skorzystał $\mathrm{z}$ finansowego wsparcia rodziny i znajomych. Przedsiębiorstwo nie przynosi dużych dochodów. Ponadto jego branża jest nierozumiana i nieszanowana przez okolicznych mieszkańców.

Inna moja rozmówczyni, młoda matka, ze względu na opiekę nad dziećmi zrezygnowała $\mathrm{z}$ pracy poza domem. Mimo to, udało jej się znaleźć źródło dochodu: na zlecenie sąsiadek bądź restauracji przygotowywała pierogi i ciasta. Jej mąż pracował na budowie, jednak jego praca była uzależniona od pory roku. Rodzinny budżet nieraz opierał sie tylko na dochodach mojej rozmówczyni. Mimo to kobieta umniejszała swój wkład w budżet, na pierwszym miejscu stawiając zajęcie męża. Dzięki posiadanej sieci znajomych moja rozmówczyni mogła szybko zebrać zamówienia na portalu Facebook.

Kolejna młoda matka, moja rozmówczyni z sąsiedniej wsi, także zajmowała sie domem i wychowaniem dziecka, podczas gdy jej maż pracował w warsztacie. Ona również wykorzystała Internet do gromadzenia dochodu: zajęła się handlem na Allegro. Jej krewni, mieszkający w Stanach Zjednoczonych, przysyłali jej przecenione ubrania, które ona mogła z dużym zyskiem sprzedać polskiemu konsumentowi. Warto zauważyć, że te przesyłki nie były prezentem, moja rozmówczyni zawsze zwracała należność (rzędu kilku dolarów). Kobieta nie uważała tego zajęcia za pracę, ale miała duże plany, także związane z kupowaniem na Allegro. Chciała przerobić rodzinny garaż na wypożyczalnię sukien ślubnych i mały salon piękności, co dałoby jej poczucie stworzenia firmy.

Inna mieszkanka regionu, osiemdziesięciotrzyletnia góralka, pomagajaca w kuchni w lokalnym pensjonacie, jako dziecko pracowała przy wypasie krów. Jako dorosła osoba została zatrudniona jako pracownica fizyczna w Kombinacie Podhale, poza tym przez lata robiła na sprzedaż wełniane skarpety i swetry. Była to praca kolektywna - grupa sąsiadek spotykała się i, zamiast oglądać telewizję, robiła na drutach. Dziś taka forma pracy zanikła, a moja rozmówczyni z powodu wieku i stanu zdrowia nie jeździ na targ i nie kupuje wełny, nie chce też jej kupić przez Internet.

\section{Praca-Robota}

Anna Malewska-Szałygin, podobnie jak Pine, opisuje państwo jako zewnętrzny dla górali, abstrakcyjny byt. Podział dom-świat zewnętrzny zawiera w sobie także opozycję wieś-miasto. Ten dualizm pociąga za sobą jasne rozróżnienie na „panów” mieszczan, ludzi zamożnych i zajmujących się pracą intelektualną, oraz na „prostych ludzi”, czyli na mieszkańców miast, niewykształconych i pracujących fizycznie. $\mathrm{Z}$ tym podziałem wiąże się kolejna opozycja: praca (właściwe „panom” zajęcia intelektualne, podejrzane i nieznane) oraz dobrze znaną góralom pracę fizyczną, w rolnictwie i fabryce, ewentualnie w turystyce (Malewska-Szałygin, 2008).

Niedawno w regionie pojawiło sie pokolenie absolwentów szkół wyższych 
(w Nowym Targu jest filia Uniwersytetu Jagiellońskiego). Część z nich powraca do rodzinnych wsi, część zostaje w mieście lub wyjeżdża za granicę. Większość z nich stara się pracować - jeśli niezgodnie z kompetencjami, to $\mathrm{w}$ odmienny od rodziców sposób: zakładając specjalistyczne firmy czy pracując tylko na etacie. Starsi górale nie rozumieją takiego trybu pracy i nie uznają go. Owo przejście jest zauważane przez moich rozmówców i traktują je raczej negatywnie. Jak stwierdził mój rozmówcakupiec: „młodzi się teraz, pani, owieczkami nie interesują. Tylko Internetem i pierdołami! I jak wyjechać za granicę! Młodzi robić nie będą na roli" (mężczyzna 48 lat, Nowy Targ, 2013). Forma pracy, forma zarabiania się wyraźnie zmienia, ale według mnie postawa wobec pracy i wspólnotowy nacisk na przedsiębiorczość wcale nie zmalały. Najjaskrawiej widać to na przykładzie jarmarku w Nowym Targu. O ile starsze osoby wolały prowadzić interes jako kupcy na targu, o tyle młodzi ludzie korzystali z Allegro, na Allegro kupowali, sprzedawali lub orientowali się w cenach; nie bez znaczenia była usługa kurierska. Narracja dotycząca jarmarku i narracja wokół Allegro były bardzo podobne, momentami identyczne, co dodatkowo zwraca uwagę na spójność praktyk starszego i młodszego pokolenia. Zmieniła się jednak ich forma, rodząc poczucie przepaści między generacjami.

\section{Pracowanie-dorabianie}

Bardzo ważnym aspektem moich badań była płeć kulturowa. Według Pine, $\mathrm{w}$ tradycyjnej rodzinie $\mathrm{w}$ drugiej połowie XX wieku podział obowiązków domowych między kobietę a mężczyznę był kluczowy. Ponadto, autorka określa przedsiębiorczość jako ważny element lokalnej konstrukcji kobiecości i macierzyństwa (2002). Jak pisze Anna Zadrożyńskiej, praca w gospodarstwie rolnym była wysiłkiem tak wielkim, że wymagała zaangażowania każdego z domowników. Rodziny musiały być kompletnymi, licznymi, stabilnymi strukturami, inaczej ich przetrwanie było zagrożone. Kompetencje męskie i kobiece były jasno określone, wszystkie obowiązki: gospodarskie i domowe należały do wspólnej kategorii i z czasem przechodziły ze starszych na młodszych członków rodziny. Sytuacja zaczęła się zmieniać po II wojnie świato- wej: wsie przestały być samowystarczalne, obowiązek pracy państwowej zaburzył wcześniejszy podział zajęć. Skończyło się partnerstwo w podziale pracy domowej: troska o porządek, jedzenie i relacje między domownikami pozostała obowiązkiem kobiet (Halawa 2006). Obowiązkom domowym odebrano rangę pracy, co umożliwiało nadanie pozorów sprawiedliwości układowi, w którym i kobiety, i mężczyźni pracują zawodowo, ale tylko po żonach i matkach oczekuje się usług opiekuńczych. Podział na strefę publiczną i prywatną miał wielki wpływ na konstrukcję nie tylko podziału obowiązków, lecz także konstrukcję płci kulturowych w ogóle (Titkow, Duch-Krzystoszek i Budrowska 2004) Według moich obserwacji w regionie istniał pewien mechanizm, który odbierał wartość pracy wykonywanej w domu, niezależnie nawet od jej rodzaju.

Winifred Poster i Zakia Salime (2002), opisując skutki programów aktywizacji gospodarczej w biednych regionach, zauważyły duże różnice w inicjatywie kobiecej (statycznej, nieoficjalnej, reprodukcyjnej) i męskiej (związanej z mobilnością, strefą publiczną. W trakcie badań często przekonywałam się, że kobiety starają się zarobić w dziedzinach uważanych za należące do kobiecych kompetencji: gotowanie, sprzątanie, tworzenie biżuterii lub ubrań. Podobnie mężczyźni przyporządkowywali swoje inicjatywy stereotypowi, zakładali firmy, działali w przestrzeni publicznej, ryzykowali, choć robili to ze wsparciem rodziny. W kontekście gminy Nowy Targ, choć sama przedsiębiorczość nie była uzależniona od płci, to kobiety wyraźnie wolały zarabiać gotowaniem, tworzeniem ubrań czy usługami kosmetycznymi. Mężczyźni raczej zostawali kierowcami, pracownikami budowy albo mechanikami. To pracę wykonywaną przez mężczyzn, związaną z mobilnością (czy też po prostu opuszczaniem domu) moi rozmówcy nazywali pracą, poważną $\mathrm{i}$ istotną w życiu. Kobiecę pracę zaś nazywano dorabianiem: taka kwalifikacja była nieraz zupełnie niezależna od finansowej efektywności zajęcia lub też wkładanego wysiłku. To góralki rezygnowały z pracy na rzecz rodzicielstwa. Nie spotkałam się z góralem, który porzuciłby zarobek dla ojcostwa. Jednocześnie, posiadanie małych dzieci często zmuszało któreś z rodziców do pozostania w domu: przedszkole było zbyt kosztowne, a babcie dalej pracowały 
(także w USA). Brak bezpłatnych instytucji, takich jak żłobki czy przedszkola prowadzi do paradoksalnej sytuacji, w której rodziny nie stać, by matka uzyskała zatrudnienie. Kobieca praca zarobkowa była najczęściej silnie związana z domowymi obowiązkami, wyrastała $\mathrm{z}$ roli matki czy gospodyni, wiązała się z ich codzienną, nieprofesjonalną wiedzą (Scott, 1998). Warto zaznaczyć, że praca zawodowa żony mogła być dla mężczyzny świadectwem jego własnej porażki. Zgodnie z lokalnymi przekonaniami góral powinien być na tyle przedsiębiorczy, by jego żona mogła pozostać w strefie prywatnej i zajęć domowych.

\section{Internet: wiek i gender}

Popularyzacja Internetu to ważny element współczesnych zmian na podhalańskich wsiach. Użycie zarówno Sieci, jak i jej infrastruktury (komputerów, tabletów, telefonów) jest uwarunkowane wiekiem (Miller, Slater 2006). Bezpośredni użytkownicy to przede wszystkim ludzie młodzi, maksymalnie przed czterdziestka. Osoby starsze dobrowolnie pozbawiają się możliwości skorzystania z Internetu: według nich komputer jest dobry i użyteczny, ale dla młodych. Niektórzy bali się, że go popsują, inni, raczej żartobliwie i z poczuciem dumy oznajmiali, że się obchodzą bez niego, jeszcze inni wykorzystywali do płacenia rachunków czy odbierania e-maili rodzinę (warto zaznaczyć, że w podobny sposób załatwiano dofinansowanie unijne). Swoboda korzystania $\mathrm{z}$ infrastruktury medialnej była odwrotnie proporcjonalna do wieku; najsprawniejszymi użytkownikami byli młodzież i dzieci, a niektóre z nich nie potrafiły jeszcze czytać.

Zgodnie z wynikami moich badań Internet był inaczej używany przez mężczyzn i inaczej przez kobiety. Sądzę, że przynajmniej narracja wokół tych strategii wynikała z dość stereotypowej (i binarnej) koncepcji płci. Mężczyźni deklarowali, że nie potrzebuja i nie lubią długiego ,siedzenia w Internecie", woleli szybko coś sprawdzić czy nawet wykonać telefon do konkretnej osoby. Szczególnie wyśmiewane było „przesiadywanie na Facebooku", które z kolei miały zajmować czas kobietom. Owe „przesiadywanie" wyglądało nieco inaczej, niż opisywali to mężczyźni. $\mathrm{Z}$ moich rozmów z prowadzacymi interesy kobietami, wynika że wykorzystują Facebooka i posiadaną sieć znajomości (rodzinę, kolegów, znajomych) do promocji swojej oferty. W wielu przypadkach Internet był jedyną płaszczyzną aktywności, jedyną możliwością inicjatywy gospodarczej, dostepna dla młodej matki, siedzącej w domu $\mathrm{z}$ dziećmi. Ponadto Internet był dla moich rozmówczyń źródłem inspiracji. W Sieci znajdowano nowe przepisy i wzory, które potem dopasowywano do lokalnych możliwości (na przykład: dostępności produktów w sklepach). Dzięki korzystaniu z tego nowego medium młode góralki mogły wirtualnie wyjść poza strefę prywatną, dekonstruując wieloletnią opozycję między domem a światem zewnętrznym.

\section{Skazani na przedsiębiorczość?}

Warto zadać pytanie: „Czy góral lub góralka mogą być nie-przedsiębiorczy?”. Wiele ze spotkanych w regionie nowotarskim osób nie prowadziło własnej firmy, lecz realizowało zlecenia lub pracowało na etacie. Zarazem nie wszystkie rodzaje inicjatywy gospodarczej spotykały się z ze społecznym zrozumieniem i uznaniem; nowatorski pomysł na biznes mógł wywołać kontrowersje. A jednak Podhalanie ciagle czuli potrzebę zatrudnienia, chcieli być aktywni i realizować swoje obowiązki. W tym momencie kategorię przedsiębiorczości można nieco poszerzyć czy też rozluźnić, a w jej miejsce zaproponować określenie „zaradność”. Sadzę, że w całej Polsce ludzie ciężko pracują, mimo trudności w „dorobieniu się”, jednak tylko podczas badań na Podhalu spotkałam się z tak silnym, oczywistym oczekiwaniem zaradności. Spotkałam ludzi, którzy ciężko, fizycznie pracowali, ale (ze względu na charakter czy trudną sytuację rodzinną) nie byli w stanie stworzyć stabilnego domostwa z posprzątaną kuchnią i wykafelkowaną łazienką. Ludzie niezaradni spotykali się ze społecznym ostracyzmem, nie $z$ wrogościa, bowiem bogatszy sąsiad w miarę możliwości pozwalał u siebie dorobić (bądź odrobić pożyczkę). Na podstawie moich obserwacji widać było, że to niezaradność kobiet głównie komentowano: nie da się tutaj nie zauważyć wpływu mitu Matki Polki (Hryciuk, Korolczuk, 2012) na wizerunek prawdziwej gaździny, która na swoich solidnych barkach powinna unieść całe gospodarstwo, razem z dziećmi, mężem i inwentarzem. Niezaradny mąż nie usprawiedliwiał nie- 
zaradnej gospodyni, zapobiegliwość żony powinna ten brak zrównoważyć. Mężczyzna „nie-przedsiębiorczy” to zwykle był też człowiek nadużywający alkoholu.

Warto zastanowić się nad kwestią samo-definiowania. W trakcie badań, podczas pobytu $w$ etnograficznym terenie, w mniejszym stopniu odczuwałam rolę języka w kształtowaniu się lokalnej przedsiębiorczości. W mojej obecności nikt nie nazwał się przedsiębiorcą, choć nie zadałam takiego pytania wprost. Wśród młodszych rozmówców, szczególnie wśród mężczyzn, zauważałam sposób wypowiadania się podobny do narracji polskich serwisów informacyjnych. Być może dziś, dwa lata od czasu zakończenia moich badań, tożsamość przedsiębiorcy jest już dla Podhalan oswojona i przyswojona.

\section{Podsumowanie}

Przedsiębiorczość, czy też zaradność, jest dla mieszkańców Podhala elementem góralskiej tożsamości. Osoby niewpisujące się $\mathrm{w}$ ten wizerunek spotykały się $\mathrm{z}$ niezrozumieniem, w skrajnych przypadkach z ostracyzmem społecznym. Wiele osób decydowało się na emigrację zarobkową. W zależności od wieku były to Stany Zjednoczone bądź Unia Europejska. Normą jest także łączenie pracy „zewnętrznej”: w mieście, na etacie bądź „szarej strefie”, z wspomaganiem rodzinnego gospodarstwa rolnego. Według moich obserwacji na podhalańskich wsiach zachodzi zmiana pokoleniowa: młodzi ludzie odchodzą od pracy fizycznej, od rolnictwa, zaczynają pracować, wykorzystując sposoby, jakie nie są w pełni rozumiane $\mathrm{i}$ akceptowane przez ich rodziców. W nowych strategiach pracy w dużej mierze wykorzystywany jest Internet, medium najczęściej niedostępne czy też niezrozumiałe dla osób powyżej czterdziestego roku życia. Zarówno metody korzystania z Internetu, jak i strategie gospodarcze są upłciowione. Tworzenie własnego, góralskiego biznesu jest także często zależne od sytuacji rodzinnej, szczególnie finansowego wsparcia rodziców. Czasem otrzymanie od rodziny dużego wsparcia finansowego nie jest wyrazem wiary $\mathrm{w}$ sukces przedsięwzięcia, a metodą „uwiązania” dziecka, które planowało emigrację. Dla młodych matek użycie Internetu jest często jedyną drogą zgromadzenia pieniędzy. Uważam, że lokalne inicjatywy gospodarcze należy analizować, mając znajomość kontekstu społecznego konkretnych osób. Każde przedsiębiorstwo jest jednocześnie wyrazem uwarunkowań rodzinnych, wiekowych i płciowych. W konkretnym kontekście społecznym przedsiębiorczość staje się kompetencją rodzinną: inicjatywa może pochodzić od jednostki, ale jej rozwinięcie zależy od relacji z najbliższymi osobami.

* Artykuł powstał na podstawie moich badań do pracy laboratoryjnej i licencjackiej, zatem część uwag i spostrzeżeń zostało zawartych także w tych dokumentach, dostępnych w archiwum IEiAK UW.

\section{Bibliografia}

Abriszewski, K. (2010). Wszystko otwarte na nowo: teoria aktora-sieci i filozofia kultury. Toruń: Wydawnictwo Naukowe Uniwersytetu Mikołaja Kopernika. Atkinson, P. i Hammersley, M. (2000). Metody badań terenowych. Poznań: Wydawnictwo Zysk i S-ka.

Besnier, N. (1996). Gossip. W: Encyclopedia of Cultural Anthropology. New York: Taylor \& Francis.

Bloor, R. (2001). Wirtualny bazar: od jedwabnego szlaku po szlak elektroniczny. Warszawa: K.E. Liber.

Bourdieu, P. (2005). Habitus i przestrzeń stylów życia. W: Dystynkcja. Spoteczna krytyka wtadzy sądzenia. Warszawa: Wydawnictwo Naukowe Scholar.

Dunn, E. (2008). Prywatyzując Polskę. O bobofrutach, wielkim biznesie i restrukturyzacji pracy. Warszawa: Wydawnictwo Krytyki Politycznej.

Glinka, B. i Gudkova, S. (2011). Przedsiębiorczość. Warszawa: Wolters Kluwer Polska.

Halawa, M. (2006). Życie codzienne z telewizorem. Warszawa: Wydawnictwa Akademickie i Profesjonalne.

Hastrup, K. (2006). Droga do antropologii. Kraków: Wydawnictwo Uniwersytetu Jagiellońskiego.

Hobsbawm, E. (2008). Tradycja wynaleziona. W: E. Hobsbawm i T. Ranger (red.), Kraków: Wydawnictwo Uniwersytetu Jagiellońskiego.

Hryciuk, R. i Korolczuk, E. (2012). Pożegnanie z Matka Polka? Dyskursy, praktyki i reprezentacje macierzyństwa we wspótczesnej Polsce. Warszawa: Wydawnictwa Uniwersytetu Warszawskiego.

Januszewski, F., Lewandowska, J. i Olszyńska, A. (2011). Potencjał social mediów w komunikacji z młodym segmentem odbiorców. Zeszyty Naukowe: Marketing przysztości: Trendy. Strategie. Instrumenty, 660. 
Kroh, A. (2011). Sklep potrzeb kulturalnych. Kraków: Prószyński i S-ka.

Latour, B. (2010). Splatajac na nowo to, co spoteczne. Wprowadzenie do teorii aktora-sieci. Kraków: Universitas.

Malewska-Szałygin, A. (2008). Wyobrażenia o wtadzy i państwie we wsiach nowotarskich 1999-2005. Warszawa: Wydawnictwo DiG i IEiAK UW.

Małanicz-Przybylska, M. (2013). Góralszczyzna istnieje...? Polska Sztuka Ludowa - Konteksty, z. 1.

Marshall, G. i in. (2004). Praca [labour]. W: M. Gordon (red.), Stownik socjologii i nauk spotecznych. Warszawa: Wydawnictwo Naukowe PWN

Miller, D. i Slater, D. (2006). The Internet: An Ethnographic Approach. Oxford: Berg Publishers.

Paprocka, W. (1976). Przemysł domowy, rzemiosło i chałupnictwo. W: M. Biernacka i in. (red.), Etnografia Polski. Przemiany kultury ludowej t. 1. Wrocław: Ossolineum.

Piecuch, T. (2013). Przedsiębiorczość. Podstawy teoretyczne. Warszawa: C.H. Beck.

Pietraszek, E. (1976) Wymiana dóbr użytkowych. W: M. Biernacka i in. (red.), Etnografia Polski. Przemiany kultury ludowej t. 1. Wrocław: Ossolineum.

Pine, F. (2002). Dealing with money: zlotys, dollars and other currencies in the Polish highlands. W: C. Humphrey i R. Mandel (red.), Markets and moralities: ethnographies of postsocialism. Oxford: Berg Publishers.

Pine, F. (2007). Góralskie wesele. Pokrewieństwo, płeć kulturowa i praca na terenach wiejskich socjalistycznej i postsocjalistycznej Polski W: R. Hryciuk i A. Kościańska (red.), Gender. Perspektywa antropologiczna t. 1. Warszawa: Wydawnictwa Uniwersytetu Warszawskiego.
Poster, W. i Salime, Z. (2002). The Limits of Microcredits: Transnational Feminism and USAID Activities in the United States and Morocco. W: N. Naples i M. Desai (red.), Women's Activism and Globalization. New York: Routledge.

Schumpeter, J. (1960). Teorie rozwoju gospodarczego. Warszawa: PWN

Scott, J. (1998). Seeing like a state. How Certain Schemes to Improve the Human Conditions Have Failed. New Haven: Yale University Press.

Sułek, E. (2005). Państwo, praca obywatel. Obowiązki obywatela wobec państwa. W: A. Malewska-Szałygin (red.), Rozmowy z góralami o polityce. Warszawa: Wydawnictwo Trio.

Sennet, R. (2010). Etyka dobrej roboty. Warszawa: Warszawskie Wydawnictwo Literackie MUZA SA.

Titkow, A., Duch-Krzystoszek, D. i Budrowska, B. (2004). Czy rodzicielstwo jest częścia pracy domowej kobiet? W: Nieodptatna praca kobiet. Mity, realia, perspektywy. Warszawa: Wydawnictwo IFiS PAN.

Tylkowa, D. (2000). Wiadomości o regionie. W: Podhale. Tradycja we wspótczesnej kulturze wsi. Kraków: IAiE PAN.

Urry, J. (2007). Spojrzenie turysty. Warszawa: Wydawnictwo Naukowe PWN.

Zadrożyńska, A. (1983). Homo faber i homo ludens. Etnologiczny szkic o pracy $w$ kulturach tradycyjnej $i$ wspótczesnej. Warszawa: Wydawnictwo Naukowe PWN.

Informacje statystyczne pochodzą z portalu Regioset.pl http://www.regioset.pl/gazeta.php?choice $=1016$ [dostęp: 15.05.2015]. 